\title{
Nationhood and identity in Conservative politics
}

\author{
Philip Lynch
}

Identification with the nation and nation state has been a central theme in Conservative politics for over a century. The party's status as a patriotic party safeguarding the constitution, Union and, for much of its history, the Empire was an important factor in its political success. The appeal of the Conservative politics of nationhood rested upon three main pillars: (i) a coherent vision of nationhood and conservative state patriotism; (ii) effective use of a patriotic discourse, which portrayed the Conservatives as a national rather than sectional party, popularised its vision of nationhood and questioned the patriotic credentials of its rivals; and (iii) a political strategy which accorded the defence of the nation state and national identity a leading place. ${ }^{1}$ But the politics of nationhood has also proved divisive periodically - tariff reform, the Irish question and European integration produced damaging intra-party divisions over British identity and party strategy in the last century. This chapter examines the Conservative politics of nationhood under William Hague, focusing on the 'English Question' and the politics of 'race'. Policy towards the European Union (EU) is examined in Chapter 8.

The end of Empire, moves towards membership of the European Community (EC), devolution and immigration posed significant challenges to the dominant One Nation perspective in the 1960s. Two contrasting positions on how to adapt the Conservative politics of nationhood emerged. Edward Heath proposed EC membership, Scottish devolution and a liberal perspective on race relations. Enoch Powell offered a post-imperial, Tory nationalist strategy that aimed to safeguard parliamentary sovereignty and national identity from the perceived threats posed by European integration, devolution and immigration. Later, the revival of British nationhood was a prominent theme within Thatcherism. The Thatcher governments made effective use of patriotic discourse, claiming to promote British interests and identity by defending the Union, limiting immigration and promoting a vision of a free market, intergovernmental EC, but also presided over a significant erosion of sovereignty and fuelled demands for devolution.

The challenges facing the Conservatives in this area were apparent in the 1990 s as divisions emerged over Europe and the government failed to 
stem the pro-devolution tide. Rather than contributing to effective Conservative statecraft, problems in the politics of nationhood provoked intra-party disputes, undermined governing competence and issue hegemony, and contributed to election defeat. ${ }^{2}$ John Major adopted a holding position but this proved akin to plugging leaks in a dyke. Whereas the Euro-sceptic right urged Major to shore up the defences against a perceived rising tide of European integration and sub-state nationalism that threatened the nation state, One Nation Tories looked to adapt pragmatically to EMU and devolution.

\section{The politics of nationhood under Hague}

Contemporary conservative thinking on the concept of the nation has coalesced around two general approaches: a civic account of the nation which looks to a limited politics of state patriotism and a cultural account (evident in the work of Roger Scruton) which stresses the pre-political basis of nationhood and a common culture. ${ }^{3}$ In the 1990s, the influence of the civic account has been apparent in Conservative discourse, but the cultural conservative perspective informs the Tory right's critique of European integration and multiculturalism. Conservative state patriotism sees a shared civic culture, allegiance to common institutions and membership of a historic community as the bedrock of national identity. The authors of a 1996 Conservative Political Centre report, Strengthening the United Kingdom, depicted Britishness as a form of constitutional patriotism denoting allegiance to the constitution and its underlying principles, but allowing for diverse identities within this framework. ${ }^{4}$ Both the civic and cultural accounts view further European integration as a threat to national sovereignty, but sovereignty is a contested concept in Conservative politics. Euro-sceptics equate it with national self-government and parliamentary authority, both of which were central to a British identity rooted in state patriotism. Pro-Europeans, for their part, see sovereignty as a capacity for influence that can be enhanced by constructive engagement in the EU.

Hague emphasised the importance of the nation to British Conservatism and sought to renew the party's position as the champion of the nation in the light of new challenges. ${ }^{5}$ To restore their political fortunes, the Conservatives had to be a national party, understanding and drawing upon British identity and values. The defining features of British identity were individualism, a spirit of enterprise, social mobility - with Hague praising the contribution of immigrants to British culture - and attachment to locality and the 'little platoons' of civil society. But common political institutions are central to British identity as they both reflect and shape these other values. With its programme of constitutional reform, support for further European integration and efforts to 'rebrand' Britishness, New Labour threatens the 
'British Way'. Hague rejected claims that Britishness was an historical invention now ripe for modernisation, arguing that it continued to be a unifying force.

Hague's Conservative nation draws upon a traditional Tory attachment to political institutions, a Thatcherite emphasis on individuals and markets, plus a belief in the virtue of local communities and civil society that underpins the 'civic conservatism' of David Willetts. Indeed, Hague's speech on the 'British way' drew on an earlier speech by Willetts on British identity. ${ }^{6}$ Willetts recognised that the Conservatives' traditional strength in the politics of nationhood was being challenged by a New Labour government determined to align itself with and modernise British identity, and by claims from historians that Britishness was a now outdated 'invented' identity. Following Michael Oakeshott, Willetts believes that the nation state should provide a framework which protects the intermediate institutions and loyalties of civil society, but should not be an 'enterprise association' striving for a homogeneous national identity. The nation state is one among a series of communities: 'a shared cultural tradition, limited government, the free market and loyalty to the central institutions of the nation state, are the integrating forces in which a conservative trusts'. The state's role in upholding the shared political culture and an integrative, state patriotism is a limited one - 'the nation state can command our loyalty as the protector of these communities but we certainly cannot look to it as one organic whole embodying detailed moral purposes which we all share'. ${ }^{8}$

The significance of the nation in Conservative politics was evident in policy on Europe, constitutional reform and race relations. European integration was perceived as a threat to self-government and national identity. For Hague a nation is: 'a group of people who feel enough in common with one another to accept government from each other's hands. This is why democracy functions best within nations.' ${ }^{9}$ Historic identities and allegiance to national institutions endure because 'national identity fulfils a basic human need to belong'. The EU does not enjoy such legitimacy or popular allegiance. Labour's programme for constitutional reform - reform of the House of Lords, incorporation of the European Convention on Human Rights, proportional representation for some elections and devolution - challenged a Conservative constitutional or state patriotism that depicted parliamentary sovereignty and the Union as bedrocks of the British state and identity. Although staunch opponents of devolution under Major, the Conservatives now accepted the 'Yes' votes in the Scottish and Welsh referendums, and backed the Good Friday Agreement though this support was eroded by the limited progress on IRA decommissioning. Predictions of a post-devolution 'break up of Britain' no longer figured prominently, but the leadership argued that the constitutional anomalies of devolution had destabilised the Union and made an English nationalist backlash more likely. On 'race', Hague described 
Britain as a 'nation of immigrants' to which ethnic minority communities had made important contributions but was uncomfortable with some aspects of multiculturalism.

\section{NEW LABOUR AND BRITISHNESS}

In New Labour, the Conservatives faced a party more confident and adept in the use of patriotic discourse than previously. The Blair government depicted itself as representing modern patriotism, revitalising both the nation state and national identity through its programme of constitutional reform, devolution and constructive engagement in the EU. The 'cool Britannia' message of creativity in the arts added more heat than light but symbolised efforts to 'rebrand' Britishness. ${ }^{10}$ The appointment of Michael Wills as the government's 'patriotism envoy' also illustrated a desire to counter Tory patriotism.

More significant were a series of speeches by ministers outlining their vision of British identity and championing New Labour as the patriotic party. ${ }^{11}$ Rather than being redundant, Britishness was being modernised through constitutional reform and a positive role in the EU. Constructive engagement in the EU was an expression of modern patriotism. Devolution would strengthen the Union by enhancing the sense of mutual interest and shared values, and bolster British identity by recognising that Britishness is a plural identity that embraces local and national allegiances. As a plural rather than ethnic identity, British culture had been enriched by immigration. Importantly, New Labour rejected Conservative claims that British identity was rooted in traditional institutions. Instead, ministers argued that nationhood arose from the collective experiences and shared values of the British people. Among the values identified were creativity and adaptability; tolerance and fair play; an outward looking rather than insular approach to the world; a commitment to both individual liberty and mutual responsibility; and a belief in the virtues of decentralisation, strong communities and civic engagement. New Labour thus blended elements of the conservative nation - Brown cited Burke's attachment to local communities and reform - with an own emphasis on community and constitutional reform to foster its 'outward looking modern patriotism'.

\section{England and the Union}

The Conservatives claimed that national institutions were central features of British national identity and thus presented constitutional reform as a threat to the 'British way'. The new leadership initially took a pragmatic position on Labour's devolution legislation before pledging to work constructively within the new institutions. As Peter Lynch discusses in Chapter 9, the Scottish Conservative Party gained greater autonomy and sought, with 
limited success, to shed its anti-Scottish tag. Reworking Conservative Unionism was a tricky task, particularly as Conservative MPs were uneasy with the perceived unfair treatment of England in the new settlement.

THE ENGLISH QUESTION

The 1997 general election defeat left the Conservatives without representation at Westminster from three of the UK's four component nations. They looked still more like an English national party and under Hague's leadership promoted English values and interests prominently. The Conservatives thus identified themselves with the countryside and rural way of life on issues such as rural crime, threats to services, the plight of farmers and fox-hunting. This was though a narrow view of English values which, coupled with the party's tone on asylum and the family, did not accord with the cultural outlook of many young urban voters. The Conservatives did not become an explicitly English nationalist party. Hague defended the Union, spoke of Britishness and the 'British way' rather than English identity (his speeches on the 'English Question' were notably reticent in defining Englishness), rejected proposals for an English Parliament and shied away from advocating major reforms to the Barnett formula. At the 2001 election, the Conservatives pledged to retain the positions of Secretary of State for Scotland and Wales but to merge the posts with other UK Cabinet roles. ${ }^{12}$

The English dimension of devolution emerged as an important theme in Conservative politics, though not the guiding principle that some predicted. Conservatives claimed that devolution to Scotland and Wales had unbalanced the Union by maintaining their preferential treatment while disadvantaging England. Constitutional anomalies such as the West Lothian Question - why should Scottish MPs at Westminster be able to vote on English matters when English MPs had no say on equivalent matters devolved to the Scottish Parliament? - undermined the Union and raised the spectre of an English backlash. Hague believed that an emerging English political identity might be productively harnessed, but was wary of both breaking too sharply with the party's Unionist tradition or lurching towards an extreme English nationalist position. A review of policy on constitutional reform would explore four options: strengthening local government; reducing the number of Scottish MPs at Westminster; restricting the voting rights of Scottish MPs; and creating an English Parliament with similar powers to those in Scotland. ${ }^{13}$

The creation of an English Parliament was the most radical option, but was rejected. Hague declared himself 'as yet unpersuaded' by the arguments in July 1999. ${ }^{14}$ The UK was 'not easily suited' to a federal model as England, with over 80 per cent of the UK's population and revenue, would be predominant. An English Parliament could undermine Westminster and further destabilise the Union. Nonetheless it found some favour within the 
party, though there was little consensus on how it might fit into the UK's institutional architecture. Lord (Kenneth) Baker's scheme proposed that an English Parliament of members from existing English constituencies would meet at Westminster for three days a week. The majority party would appoint a First Minister and Executive with responsibility for 'domestic' English law. A UK Parliament of 350 members would handle economic, foreign and defence policy. ${ }^{15}$ Others proposed 'devolution in the round' with an English Parliament operating within a federal United Kingdom, or an independent English state. ${ }^{16}$

Those MPs most critical of the 'unfair' treatment of England and supportive of an English Parliament came from the Euro-sceptic right. The disproportionate number of Scottish MPs at Westminster, their participation in votes on 'English' matters, the number of Scottish Cabinet Ministers and the higher levels of public spending per head of population in Scotland than in England were cited as examples of bias against England. Teresa Gorman felt that the Conservatives should no longer make compromises for the sake of the Union, but should champion English rights and identity. She launched an unsuccessful Bill, supported by David Davis and Eric Forth, to provide for a referendum on an English Parliament. ${ }^{17}$ However, few Conservative heavyweights lent their support: Iain Duncan Smith, Kenneth Clarke, Ann Widdecombe and Peter Lilley all expressed doubts. ${ }^{18}$

The official Conservative position, announced in July 1999, was that 'English votes for English laws' provided the optimal answer to the West Lothian Question. Under Hague's plan, Scottish MPs would lose their right to vote on legislation on non-Scottish 'domestic' matters, leaving English MPs an exclusive say over English law and spending plans. The Speaker would identify those Bills that related only to English matters as 'English Bills'. They would be debated and voted on by English MPs at each stage of the legislative process in the House of Commons. In practice, as the National Assembly for Wales does not have primary legislative power, Bills on health, education and the like would be certified as 'English and Welsh Bills' with MPs representing English and Welsh constituencies voting. Removing the right of Scottish MPs to vote on English legislation would be among the first actions of a Conservative government. ${ }^{19}$

Hague claimed that his scheme was the optimal solution to the 'West Lothian Question', requiring neither an English executive nor special 'English days' at Westminster. However, there were potential problems with the 'English votes for English law' plan. The withdrawal of voting rights from Scottish MPs could leave a future UK government without sufficient support to pass English legislation. Hague argued that Parliament would then be able to check the executive effectively, but Labour would suffer under this scenario given the low levels of Conservative support in Scotland. Furthermore, it would not be easy to identify exclusively English legislation as 
under the Barnett formula decisions on spending in England impact upon the size of the block grant allocated to the Scottish Parliament. Denying Scottish MPs a say on English legislation would reduce their influence over public expenditure in Scotland.

The government opposed the proposal, though the House of Commons Procedure Committee did recommend that existing provisions allowing the Speaker to designate legislation as relating exclusively to Scotland be adapted to provide for English (or English and Welsh) Bills. ${ }^{20}$ These would be referred to a Second Reading Committee made up entirely of members of the appropriate territory. However they would have to be approved by the House as a whole. The Conservatives did not fully support this plan; the government rejected it. Nor was Labour's plan to revive the Standing Committee on Regional Affairs - consisting exclusively of English MPs - wholly endorsed, as its remit would be regional affairs rather than English matters. Four Conservatives became standing members of the Committee but, when it finally met in May 2001, only one Tory turned up even though all English MPs were entitled to attend. ${ }^{21}$

The Conservatives supported a reduction in the number of Scottish MPs sitting at Westminster but saw this as an insufficient answer to the 'English Question'. Scotland has some fourteen seats more than it would have if Scottish constituencies were of equivalent size to the English average of 72,000 constituents per seat. The government indicated that the number of Scottish seats at Westminster would be reduced to between fifty-seven and sixty, but this would not take effect until the general election after next, whereas the Tories sought immediate change.

Finally, the Conservatives opposed both the Regional Development Agencies (RDAs) established by the government and Labour's proposals for elected regional assemblies in England. The RDAs were condemned as costly and bureaucratic, duplicating or taking over functions best carried out by local councils, and would be abolished. Regional government was not the answer to the 'English Question': few parts of England had a strong regional identity and those that did (for example, Cornwall) might find themselves part of an artificial entity.

Hopes that the Conservatives might benefit from a re-awakening of English identity and backlash against the anomalies of devolution were largely unfulfilled. Surveys suggested that since devolution British identity had weakened, as the number of people describing themselves as being more Scottish, Welsh or English than British increased. ${ }^{22}$ Although a greater number of people in England were now more likely to identify themselves as English rather than British, there were few signs of either widespread or deeply felt resentment about the treatment of England. ${ }^{23}$ Support in England for Scottish and Welsh devolution increased but only a minority - even of those identifying themselves as English rather than British - wanted devolution for England, 
either in the form of regional assemblies (15 per cent support) or an English Parliament (18 per cent). Those with a strong English identity were more Euro-sceptic but this did not produce a strong identification with the Conservatives. Although the Tories were seen as more English than Labour, they scored less than 30 per cent support among those with a strong English identity, trailing Labour. ${ }^{24}$

\section{The politics of 'race'}

It was a case of 'one step forward, but two steps back' for Conservative policy on 'race' issues during Hague's leadership. On a positive note, Hague continued efforts to attract greater ethnic minority participation in, and support for, the Conservatives. But the net results were disappointing, largely because of the negative signals that emanated from Hague's tough position and populist rhetoric on asylum, and by evidence of continued hostility to multiculturalism on the Tory right.

Early in his leadership, Hague stressed his social liberal credentials, praising the contributions made by immigrants to British life and promoting a 'patriotism without bigotry'. He firmly rebuffed Lord Tebbit's claim that 'one cannot ... be loyal to two nations ... it perpetuates ethnic divisions because nationality is in the long term more about culture than ethnics'. The new leader and his fiancée also made a symbolic visit to the 1997 Notting Hill carnival but media coverage focused on unsuccessful efforts to improve Hague's public image. Despite the early promise, the Conservatives would develop a hardline policy and populist rhetoric on asylum and fail to tackle racism in the Conservative Party by the end of his tenure.

ASYLUM

Asylum emerged as a central theme in Conservative politics midway through Hague's leadership when it became part of a 'core vote strategy' aimed at shoring up traditional Tory support and using populist themes to maximise coverage of the Conservative agenda. The government had introduced a number of measures to tackle the increase in asylum applications - a voucher system, the dispersal of asylum seekers across the UK and civil penalties on hauliers caught bringing illegal immigrants into the UK - some of which the Conservatives opposed. Policy on 'bogus asylum seekers' was only briefly mentioned in the 1999 Common Sense Revolution which promised to reinstate the 'safe countries' list, end amnesties and 'use more detention'.

Within a year asylum had moved close to the top of the Tory agenda as applications continued to rise and Ann Widdecombe established her position as Shadow Home Secretary. The Conservatives made asylum a key issue in the 2000 local elections, accusing Labour of making Britain 'a soft touch for the organised asylum racketeers who are flooding our country with bogus 
asylum seekers' and highlighting the costs of asylum support borne by some local authorities.

In a keynote speech mixing reasoned argument and populist prescription, Hague set out his plans for tackling abuse of the asylum system. ${ }^{25}$ He claimed that a Conservative government would uphold Britain's 'proud tradition of offering sanctuary to those who are fleeing injustice and wrong'. But this tradition of hospitality was now at risk - not from racism or an unwillingness to accept genuine refugees in Britain, but from a flawed asylum regime. The international system for dealing with refugees put in place by the 1951 Geneva Convention was no longer working effectively in a world of mass emigration - a view shared by the government. Hague claimed that up to 80 per cent of those claiming asylum had manifestly unfounded cases but few were speedily removed from the country. Furthermore, the asylum system was being abused by human trafficking and organised provision of false documents. But Hague also blamed the government for the pressure on the asylum system, attacking the cost and effectiveness of its policies. (Though at least some of the blame for the backlog of cases could be traced to a troubled contract to update the Immigration and Nationality Directorate computer system agreed by the Major government.)

The most draconian of the Conservative proposals on asylum was that all new applicants be detained in secure reception centres until their cases had been determined. Though costly, it was argued that detention would ensure that asylum seekers had access to support without the need for a voucher system and would make it easier for a new Removals Agency to deport those whose cases had been turned down. Decisions on asylum cases and the appeals process would be speeded up. A list of 'manifestly safe' countries (from where the cases of asylum seekers would normally be deemed unfounded) would be restored. Finally, the Conservatives would press the other signatories of the Dublin Convention - under which asylum seekers should be dealt with by the first safe country they reach - to implement the Convention.

This hard-line position was welcomed by the Tory right and by the (former) Tory press but liberal and One Nation Conservatives - including Steven Norris who as party vice-chairman was responsible for improving ethnic minority participation - were critical of the authoritarian nature of party policy and of Hague's populist rhetoric. Questions about the cost and practicality of housing all asylum applicants prompted speculation about a policy rethink, but Hague stuck at the general election by his position of detaining 'all new applicants for asylum, whether port applicants or incountry applicants, in reception centres until their cases have been heard'. ${ }^{26}$ Widdecombe was also critical of Labour's proposals for changes to the migration system allowing more skilled workers to settle in the UK, claiming that the existing work permit system was sufficient. 
In his most controversial speech, Hague warned the 2001 Conservative spring forum that Britain after a Labour second term would be a foreign land'. 27 The phrase did not appear in the section of the speech dealing with asylum (on which Hague said nothing new), but referred primarily to the abolition of sterling. The media, encouraged by Conservative spin doctors, did though connect the 'foreign land' warning with Conservative policy on asylum. The speech was widely condemned in the press; even the Sun dubbed it extremist. Asylum remained an important theme in the party's general election campaign - Hague and Widdecombe visited Dover - but Hague was reported to have vetoed an election broadcast focusing on the issue.

There were significant parallels between Margaret Thatcher's policy on immigration and that of Hague on asylum. Both criticised the existing migration regime and sought firmer rules limiting entry into the UK while claiming to be acting in the interests of Britain's ethnic minority community. Hague's populist rhetoric echoed that of Thatcher - both claimed to be pursuing a 'common sense' agenda that reflected the views of the British people, depicted Labour as a 'soft touch' and used phrases such as 'flooding'.

\section{MULTIETHNIC BRITAIN}

Hague stressed that the Conservatives were committed to an inclusive, tolerant society in which racism had no place, and praised the contributions ethnic minorities had made to British life. Campaigning in Bradford, he said:

The fact that the United Kingdom is made up of different communities with a variety of different cultures and traditions greatly enriches our national life. Whatever our religious beliefs or ethnic background, I believe passionately that the United Kingdom belongs to us all. It has never mattered to me whether people are Muslim, Christian, Hindu, Sikh, Jewish, White, Black or Asian. As far as I am concerned we are all as British as each other. ${ }^{28}$

The Thatcher and Major governments had adopted a pragmatic, non-interventionist approach to race relations. Good race relations were best achieved through equality of opportunity in a meritocratic free market economy, backed up by existing anti-discrimination legislation. In tandem with this market liberal approach, however, many Conservatives held a cultural integrationist perspective in Conservative thought which believed that successful integration required that ethnic minorities accept the primacy of British values. Both strands of thought were evident during Hague's leadership. While recognising that Britain contained diverse cultures, Hague noted that Britain had a 'predominant national culture' and rejected the Parekh Report's suggestion that national identity be 're-imagined' as a 'community of communities' because 'Britishness has systematic racial connotations'. ${ }^{29}$

The Conservatives initially welcomed the Macpherson Report into the handling of the Stephen Lawrence case by the Metropolitan Police and for 
the most part backed the action proposed by the government, including the 2000 Race Relations (Amendment) Bill. The leadership accepted the Report's definition of 'institutional racism' but was concerned that it would undermine the police. ${ }^{30}$ But in December 2000, Hague claimed that the Report had 'contributed directly to a collapse of police morale and recruitment and has led to a crisis on our streets' with street crime increasing as the police shied away from 'stop and search'. ${ }^{11}$

\section{'RACE' AND THE CONSERVATIVE PARTY}

Since the late 1970s, the Conservative Party has tried to increase its black and Asian membership and attract greater ethnic minority electoral support. Hague followed Major in pledging to increase party membership from ethnic minorities and boost the number of black and Asian Conservative candidates. He established a Cultural Unit (replacing the One Nation Forum) to increase ethnic minority participation, change attitudes in the party and offer advice on multiculturalism. But its efforts brought only limited success. The Conservatives fielded sixteen candidates from ethnic minorities at the 2001 election (up from ten in 1997), but only one candidate, Shailesh Vara in Northampton South, was selected for a winnable seat and he was narrowly defeated. ${ }^{32}$ Two Asian candidates - Bashir Khanbai and former MP Nirj Deva - were elected in the 1999 European parliamentary election. But Andrew Lansley and John Bercow (a former Monday Club member) recognised that not enough had been done to promote ethnic minority candidates and tackle racism in the party. ${ }^{33}$

Major had courted ethnic minority votes, particularly those of middleclass Asian voters who were said to share Conservative values of enterprise and authority. Although this strategy was of dubious merit, the party won some 25 per cent of the British Asian vote in 1997. ${ }^{34}$ Hague told an audience of British Muslims that:

We can all share the emphasis that members of the Muslim community place on enterprise, on hard work, on education, on respect for others, on standing up for what is right, on carrying out our obligations to others, on the importance to society of marriage and the family, of community and tradition, and, through your religion, the need for a spiritual dimension to our lives. ${ }^{35}$

The prospect of greater ethnic minority support has been adversely affected by the persistence of cultural conservative views on the Tory right and the negative experiences of potential black and Asian candidates. ${ }^{36}$ The anti-immigration nationalist wing of the party has been in retreat for some years, but was still able periodically to embarrass the leadership. The most damaging example occurred shortly before the 2001 election when retiring MP John Townend told a local association meeting that: 'our homogeneous 
Anglo-Saxon society has been seriously undermined by the massive immigration - particularly Commonwealth immigration - that has taken place since the war'. ${ }^{37}$

Townend also blamed asylum seekers for rising crime and said that Enoch Powell's predictions about immigration had been proved right. Hague denounced the comments as 'wholly unacceptable'. The leaders of the main parties had meanwhile signed a Commission for Racial Equality (CRE) compact not to exploit race issues in the election. Michael Ancram sent a memo to Conservative parliamentary candidates warning them to 'avoid using language which is likely to generate racial or religious hatred', but did not give clear guidance on whether they should individually sign the CRE compact. Although Hague had technically signed on behalf of his party, the CRE revealed that a number of Conservative MPs had refused to sign.

The controversy was fuelled when Townend wrote that 'the concept of a multicultural, multiethnic, multilingual society is a mistake and will inevitably cause great problems', then said that Robin Cook saw the British as a 'mongrel race'. This provoked a furious response from Lord Taylor of Warwick, a black life peer who experienced racism in the party when standing as parliamentary candidate for Cheltenham in 1992. Taylor accused Hague of weak leadership, demanded that Townend be expelled from the party and intimated that he might defect to Labour if action wasn't taken. ${ }^{38}$ Hague belatedly forced Townend to apologise and withdraw his remarks or be expelled from the party, while Taylor was asked to confirm his loyalty. Eleven black and Asian candidates also signed an open letter, drawn up by Ancram, declaring that the Conservatives were an 'open and tolerant party' in which racism had no place. Thatcher warned that 'a multicultural society will never be a united society' during the election campaign but her comments did not attract much attention. ${ }^{39}$

There is little evidence to suggest that asylum policy brought electoral dividends. The Tories did not regain any seats in Kent where the pressures on the asylum system were particularly apparent. A Gallup poll taken shortly after the Townend affair gave the Conservatives only a narrow lead: 43 per cent identified them as the best party to handle the asylum issue compared to 36 per cent choosing Labour. ${ }^{40}$ Other polls showed public concern about levels of immigration and support for tough action on asylum, but a lack of faith in the policies of either main party. ${ }^{41}$ Conservative supporters were more likely to believe that Britain was a 'soft touch' on asylum and that there were too many immigrants in Britain. ${ }^{42}$ But liberal attitudes on race relations and skilled migration were becoming more prevalent. Gallup reported that 73 per cent agreed that Britain was a 'multicultural, multiracial society' with 69 per cent believing this was a 'good thing', while Labour enjoyed a healthy 56-27 per cent lead over the Conservatives on race relations. This, together with Conservative divisions on race and the limited impact of its asylum 
message, allowed Labour to promote a positive message on race without suffering an electoral backlash. ${ }^{43}$

\section{Conclusion}

Two broad visions of British identity are evident in contemporary British political discourse. The first is a pluralist perspective on Britishness that emphasises the multinational character of the UK state and seeks an updated British identity. It supports constitutional reform, devolution, constructive engagement in the EU and government action to improve race relations. One Nation Conservatives embraced a similar vision in the 1970 s, but this perspective is now most clearly associated with New Labour. The second is an authoritarian individualist perspective, primarily associated with Thatcherite Conservatives, which views enterprise, individual liberty and state authority as the key attributes of British identity. It supports the Union but in seeking to safeguard parliamentary sovereignty and the constitutional status quo, has tended to treat the UK as a unitary state. The focus has now shifted to the 'English dimension' of devolution with authoritarian individualists advocating English interests and identity. This is also a Euro-sceptic perspective: European integration is viewed as a threat to the nation state and national identity. The authoritarian individualist perspective does not prioritise cultural homogeneity like the old Tory right, but is wary of multiculturalism and holds that ethnic minorities should accept British values.

The trend in the Conservative politics of nationhood under Hague's leadership was clearly towards a stronger authoritarian individualist perspective though there were limits to this. The party accused New Labour of undermining Britishness, adopted a firmer Euro-sceptic line by ruling out EMU entry for two Parliaments and calling for greater flexibility, and demanded 'English votes for English laws'. But Hague did not move as far in this direction as some on the Tory right would have liked - he did not rule out membership of the single currency as a matter of principle and did not support the creation of an English Parliament. The Conservatives also embraced parts of the pluralist perspective on Britishness. The party had to abandon its implacable opposition to devolution after the Scottish and Welsh referendums, and sought to develop a more pragmatic Unionism that accepted devolution in principle - though urging fairer treatment of England - and continued to make a positive case for the Union. Hague also recognised that Britain was a multiethnic society and that British identity should embrace cultural diversity, though concerns about the implications that multiculturalism may have upon shared values were also apparent.

The nation and nation state regained a central place in Conservative politics after the 1997 election defeat. However, each of the three core elements of an effective Conservative politics of nationhood - a coherent 
concept of the nation, effective use of patriotic discourse and a political strategy that offers an electorally attractive and politically viable defence of the nation state and national identity - posed difficult questions for the party. Firstly, the Conservatives have yet to address fully questions about the nature of Britishness, particularly the relationship between English and British identities, and the appropriate balance between cultural diversity and shared values. Secondly, the party found that its discourse of identity and patriotism lost some its potency as New Labour became more adept at employing the language of nationhood itself. Finally, the Conservatives need to consider the lessons of the failure of Hague's brand of patriotic politics. A populist Tory nationalist strategy built around Euro-scepticism, defence of English interests and a tough line on asylum did establish a distinctive, high-profile Conservative strategy, but it had little electoral appeal beyond the party's core support.

\section{Notes}

1 See P. Lynch, The Politics of Nationhood: Sovereignty, Britishness and Conservative Politics (London, Palgrave, 1999).

2 On Conservative statecraft, see J. Bulpitt, 'The discipline of the new democracy: Mrs Thatcher's domestic statecraft', Political Studies, 34:1 (1986) 19-39.

3 R. Scruton, 'In defence of the nation', in J. C. D. Clark (ed.), Ideas and Politics in Modern Britain (London, Macmillan, 1990), pp. 53-86.

4. CPC National Policy Group on the Constitution, Strengthening the United Kingdom (London, Conservative Political Centre, 1996), pp. 15-16.

5 W. Hague, 'Identity and the British way', speech to the Centre for Policy Studies, London, 19 January 1999.

6 D. Willetts, 'Who do we think we are?', speech to the Centre for Policy Studies, London, 8 October 1998. He outlined five features of British identity: individualism, a spirit of enterprise, social mobility, identification with the local and political institutions.

7 D. Willetts, Modern Conservatism (London, Penguin, 1992), p. 184.

8 Willetts, Modern Conservatism, p. 106.

9 W. Hague, 'The potential for Europe and the limits to union', speech to INSEAD Business School, Fontainebleau, 19 May 1998.

10 See M. Leonard. Britain TM. Renewing our Identity (London, Demos, 1997).

11 G. Brown, 'Spectator/Allied Dunbar Lecture - Outward bound', The Spectator, 8 November 1997; G. Brown, 'This is the time to start building a greater Britain', The Times, 10 January 2000; T. Blair, 'Speech on Britishness', London, 28 March 2000; R. Cook, 'Celebrating Britishness', speech to the Centre for the Open Society, London, 19 April 2001.

12 W. Hague, 'Play the Scottish card', Scotland on Sunday, 4 March 2001.

13 W. Hague, 'Change and tradition: thinking creatively about devolution', speech to the Centre for Policy Studies, London, 24 February 1998.

14 W. Hague, 'Strengthening the Union after devolution', speech to the Centre for Policy Studies, London, 15 July 1999.

15 Hague, 'Strengthening the Union after devolution'.

16 Compare J. Barnes, Federal Britain - No Longer Unthinkable? (London, Centre for 
Policy Studies, 1998) and S. Heffer, Nor Shall my Sword. The Reinvention of England (London, Weidenfeld \& Nicolson, 1999).

17 T. Gorman, A Parliament for England (Cheltenham, This England Books, 1999). The Referendum (English Parliament) Bill, No. 9, 1997-98. The Second Reading Debate took place on 16 January 1998.

18 A. Sparrow, 'Big guns shoot down English Parliament', Daily Telegraph, 9 October 1998.

19 W. Hague, 'A Conservative view of constitutional change', speech at Magdalen College, Oxford, 13 November 2000.

20 'The Procedural Consequences of Devolution', Fourth Report of the House of Commons Procedure Committee 1998-99, HC 185.

21 See R. Masterman and R. Hazell, 'Devolution and Westminster', in A. Trench (ed.), The State of the Nations: The Second Year of Devolution in the United Kingdom (London, Constitution Unit, 2001), pp. 218-20.

22 J. Curtice and B. Seyd, 'Is devolution strengthening or weakening the UK?', in A. Park et al. (eds), British Social Attitudes: The 18th Report (London, Sage, 2001), pp. 227-44.

23 J. Curtice and A. Heath, 'Is the English lion about to roar? National identity after devolution', in R. Jowell et al. (eds), British Social Attitudes. The 17th Report (London, Sage, 2000), pp. 155-74.

24. Curtice and Heath, 'Is the English lion about to roar?', pp. 169-71.

25 W. Hague, 'Common sense on asylum seekers', speech to the Social Market Foundation, London, 18 April 2000.

26 P. Wintour, 'Tories retreat on asylum detentions', Guardian, 29 November 2000; W. Hague 'Conservatives will make Britain a safe haven for genuine refugees', speech at Dover, 18 May 2001.

27 W. Hague, 'The last chance election for Britain', speech to the Conservative Party Spring Forum, Harrogate, 4 March 2001.

28 W. Hague, 'We will renew Britain's civil society', speech in Bradford, 1 June 2001.

29 W. Hague, 'Why I am sick of the anti-British disease', Daily Telegraph, 13 October 2000; The Future of Multi-Ethnic Britain (London, Profile Books/The Runnymede Trust, 2000), Part One.

30 'The Stephen Lawrence Inquiry Report' ('The Macpherson Report'), Vol. 1 (London, HMSO, 1999) Cm 4262-I. The Report (para. 6.34) defined institutional racism as the collective failure of an organisation to provide an appropriate and professional service to people because of their colour, culture or ethnic origin. It can be seen or detected in processes, attitudes and behaviour which amount to discrimination through unwitting prejudice, ignorance, thoughtlessness and racist stereotyping which disadvantage ethnic minority people'.

31 W. Hague, 'Common sense on crime', speech to the Centre for Policy Studies, London, 14 December 2000. See also W. Hague, 'Where was Jack Straw when Damilola died?', Sunday Telegraph, 17 December 2000.

32 D. Butler and D. Kavanagh, The British General Election of 2001 (London, Palgrave, 2002), pp. 197 and 191.

33 See the comments by A. Lansley in R. Sylvester and P. Johnston, 'Racism endemic in Tory party', Daily Telegraph, 3 September 2001; and by J. Bercow at the 2000 Conservative Party annual conference fringe meeting 'Being Blue and Black in an Inclusive Society', www.millenniumb.f9.co.uk/Tory_fringe200o.htm.

34 S. Saggar, 'A late, though not lost, opportunity: ethnic minority electors, party strategy and the Conservative Party', Political Quarterly, 69:2 (1998) 148-59.

35 Hague, 'We will renew Britain's civil society'. 
36 On the latter, see R. Ali and C. O'Cinneide, Our House? Race and Representation in British Politics (London, Institute of Public Policy Research, 2002).

37 'We should have acted sooner - extracts from John Townend's speech', Daily Telegraph, 29 March 2001. Subsequent events are described in S. Walters, Tory Wars. Conservatives in Crisis (London, Politico's, 2001), pp. 146-63.

38 J. Taylor, 'The Conservative Party cannot contain Townend and people like me', The Times, 30 April 2001.

39 Walters, Tory Wars, pp. 174-9.

40 A. King, 'Voters support Hague's stand on immigration and asylum seekers', Daily Telegraph, 12 May 2001.

41 MORI poll in the Mail on Sunday, 7 January 2001, www.mori.com/polls/ 2001/ms010106.shtml; A. Travis, 'The way we see it', The Guardian, 21 May 2001. Here, ICM found that 51 per cent would support a 'green card' style system for economic migration to the UK.

42 MORI poll, 'Britain today - are we an intolerant nation?', 23 October 2000. www. mori.com/polls/2000/rd-july.shtml.

43 See S. Saggar, 'The race card, again', in P. Norris (ed.), Britain Votes 2001 (Oxford, Oxford University Press, 2001), pp. 195-210. 